\title{
John Locke's thoughts on human rights: Exploring the contemporary discourse in the West
}

\author{
Hoa Thi Kim Do - Michal Valco
}

DOI: 10.18355/XL.2022.15.01.07

\begin{abstract}
Our paper examines John Locke's legacy pertaining to the topic of human rights as it is exemplified and manifested in the contemporary philosophical discourse in the West. Besides core philosophical issues, we also notice the ethical and/or religiousethical aspects of the current debates. Our assessment starts with identifying significant contextual influences on Locke's thinking. In the next section, we provide a concise summary of Locke's key contributions with implications for philosophy and ethics and the existing socio-political models of governance. The final section of our paper focuses on analyzing critical themes of the contemporary discourse related to Locke's ideas (with the primary focus on property rights) in the West.

Key words: John Locke, natural rights, state of nature, epistemology, right to property, the value of human labor
\end{abstract}

\section{Introduction}

John Locke (1632-1704) has since long been considered one of the most profound political thinkers/philosophers of the modern age. (Tuckness, 2018) His known philosophical and political views related to the governance of human societies, however, rest on incisive reflections concerning epistemology, which tends to be overlooked. (Nickel, 2019) Furthermore, Locke's reasoning arises from within a certain conceptual framework, shaped by a concrete vision of reality which gives Locke's views coherence and direction. Our paper examines John Locke's legacy pertaining to the topic of human rights (known to Locke as 'natural rights') as it is exemplified and manifested in the contemporary philosophical discourse in the West. Besides core philosophical issues related to epistemology, philosophical and religious anthropology, as well as ethics, we also notice the ethical and/or religious-ethical aspects of the current debates. Our assessment starts with identifying significant contextual influences on Locke's thinking. In the next section, we provide a concise summary of Locke's key contributions with implications for philosophy and ethics, as well as the existing socio-political models of governance. The final section of our paper focuses on analyzing key themes of the contemporary discourse related to Locke's ideas in the West.

\section{John Locke's Notion of 'Natural Rights' pertaining to Humans Contextual influences on Locke's thinking}

John Locke's parents were English Protestants, more precisely Puritans, who understood the value of good education for their son. Their family wealth, however, did not make it possible to safeguard the best schools for their son, which is why they had to rely on outside help. John Locke found his sponsor and patron in the figure of a former commander of the English Protestant infantry, Alexander Popham (16051669). Due to his political experience in the House of Commons (between 1640-1669), Popham was not only skilled as a military leader but also as a politician. In addition, John's father served under Popham as his commanding officer, so there was a natural level of trust between Popham and Locke's family. Popham secured the best available education for young Locke, sending him first to the Westminster School in London and next to Oxford's Christ Church College. Locke's mind never found much interest in either the classical Greek education or the Medieval studies still offered at 
European universities. Instead, he found inspiration in Descartes, Willis, Hooke, Boyle, and other more recent thinkers (most of whom were actually his contemporaries). The rationalism of Descartes, along with his typical 'Cartesian dualism,' failed to satisfy Locke's intellectual hunger for long, however. Instead of Continental rationalism and Idealism, Locke turned to the empirical method as a more secure guide/foundation of knowledge. English Empiricism thus became his home philosophical turf upon which he built much of philosophical reflection and scientific endeavor. The most important influence among the empirical thinkers came undoubtedly from Sir Francis Bacon, whom Locke came to appreciate as a clear thinker with a robust scientific method. The scientific method in question is that of inductive reasoning based on a methodical gathering of empirical evidence through repeated experimentation. Hence the origin of the term 'experimental philosophy,' which Locke used when referring to his way of reasoning. Besides epistemology, philosophy in general and political philosophy, Locke became interested in medicine as well. In fact, he became a licensed physician and entered the services of Lord Anthony A. Cooper (1621-1683), who was later to become the Lord Chancellor of England (namely in 1672). The connection with Lord Ashley Cooper made a lasting impact on Locke's career and political thinking, as he was able to follow Cooper on his trips and advise him on his political maneuvering. Locke learned much about reallife politics during this time and made connections with other significant people, some of whom were intellectuals and academicians. The most distinguished among these was perhaps Thomas Sydenham (1624-1689), who became essential for the development of Locke's mature views on medicine and natural philosophy.

In general, Locke's experience as a physician and political advisor helped shape his philosophical views and crystalize his scientific approach - to medicine as well as to matters of political philosophy. This experience included several trips to foreign countries, namely to the North American colonies and to the Netherlands, where he met the then famous Benedict B. Spinoza (1632-1677). While he did not share Spinoza's metaphysical presuppositions regarding the 'monistic' nature of reality, Locke was inspired by Spinoza's assertions that the realm of the state must be separated from that of the Church. Such ideas were relatively new in his time and, as such, were generally frowned upon. In addition, Locke was interested in the question of tolerance. During his visit to the Netherlands, he became increasingly convinced that tolerance is an indispensable element in a rightful, sustainable ordering of any human society. This idea, too, was promoted by Spinoza, and Locke seemed to have appreciated Spinoza's arguments in this respect. (Do \& Valco, 2021b: 24) Furthermore, "his experience of the English Restoration of the Stuart monarchy under King Charles II, which began in 1660 (when Locke was merely 28 years old) and ended with the return of Mary II, the king's sister, with her husband William of Orange in the so-called 'Glorious Revolution' of 1688, made an especially deep impact on Locke's political thinking. It was during this time that Locke experienced and, indeed, more fully understood what the absolute power of a monarch could mean to a man's life and the life of a society." (Do \& Valco, 2021b: 24-25; Cf. Breakey, 2017) It was during these turbulent times that Locke fully recognized the viciousness and oppressiveness of absolute monarchy as a political system. This development also explains Locke's animosity to Robert Filmer (1865) and the ideas of Thomas Hobbes (Hobbes \& Missner, 2016). The question of political legitimacy must be, according to Locke, connected with the consent of the governed and not be derived arbitrarily from a self-serving notion of the 'divinely instituted order' that reflects the heavenly reality on earth. He demonstrated Filmer's inadequacy as an exegete and convincingly showed that the circle of terror and violence experienced around the globe stems precisely from the misguided pretension of rulers who purport to be divine representatives on earth. Locke's notion of 'natural rights' served as an antidote to

XLinguae, Volume 15 Issue 1, January 2022, ISSN 1337-8384, eISSN 2453-711X 
such omnipresent violence and provided the needed foundation for a new theory of 'social contract.'

\section{A Summary of Locke's key contributions with implications for philosophy and ethics}

To understand the nature and value of Locke's key intellectual contributions, we propose classifying these into three distinct categories: (1) scientific method, (2) epistemology, (3) political philosophy. We have already discussed Locke's turning away from the Cartesian rationalist argumentation method and the continental idealist approach in favor of the empirical method based on experimentation and inductive reasoning. As mentioned above, Locke owes much of the development in his scientific methodology to Sir Francis Bacon. We will now turn to two other key areas of his intellectual contribution, namely his work in epistemology and political philosophy. We will show how his epistemological approach tied in with the content of his philosophy. More importantly, we will demonstrate how Locke's metaphysical and metanarrative presuppositions shaped the contours of his reasoning and conditioned his conclusions.

The breakthrough work in epistemology that put John Locke on the philosophical map was his An Essay Concerning Human Understanding, published in 1689. Unlike many of his predecessors and countless contemporaries, Locke took a more humble approach when it came to the capacity and limits of human reason. He rejected the old, scholastic (Aristotelian) way of reasoning, accusing it of being too speculative. Locke was instead looking for a "sure footing" in the process of knowing, which prompted him to draw new, more sober lines of the limits of human epistemological endeavors. Abstract inferences as part of human rational reflection were not completely dismantled, however. Locke realized that they, too, had their place in the process of knowing, providing they occurred within the context of human lived experience. Sensation and reflection thus go hand in hand, but reflection must be based on prior sensation. The empirical experience thus became foundational for Locke. Speculations that could not be warranted the individual or collective/historical experience represented an illegitimate extension of human inquiries "beyond their capacities." (Locke, 1975: 7)

There is a teleological aspect to the human process of knowing - namely, the ability to adapt to the challenges of the changing environment. Locke also emphasized the importance of language as the acquired ability to verbalize and conceptualize knowledge. He pointed out that "human ideas verbalized in language, inadequate as they may be, play an important role in this process." (Do \& Valco, 2021a: 4) True knowledge must be distinguished from ad hoc, unfounded inferences, and speculations. Again, the connection with lived experience remains vital here, which is why Locke labels true scientific knowledge as 'natural philosophy.' Natural philosophy "reflects critically on the established ideas about the nature of things and helps converge the nominal essence (i.e., human preliminary ideas expressed in language) on the real essence (true nature of the material world). Such an optimistic epistemological outlook prompts Locke to believe that the human thinking subject can actually know substances even if imperfections and obscurities taint his/her ideas of them. Locke distinguishes 'modes' from 'substances' to make room for 'complex ideas' that order substances in the human mind to facilitate higher comprehension." (Do \& Valco, 2021a: 4)

The intimate connection between lived experience and subsequent rational reflection is constitutive to the overall character of Locke's natural philosophy. It manifests itself, among other places, in the intertwining between moral virtues and intellectual maturity and the exercise of one's civic freedoms and rights. Educated reason in and of itself is not a guarantee of a mature exercise of free choices for the public good and leading to personal wellbeing. In this sense, Locke remains connected to Aristotelian 
'virtue ethics' and 'virtue epistemology.' Only a well-educated, well-informed reason, imbued with the capacity to think critically (also self-critically), can become the starting point for a true, scientific (i.e., empirically/experientially based and relatively unbiased) reflection providing it is also morally formed and informed. Freedom is thus not an abstract category designating the arbitrary volitional choices of a selfserving, self-referential individual, but rather a teleological category related to pursuing truth, justice, civility, industriousness, mutual respect, and the respect for the rights of others. (Rickless, 2020) Locke also believes that human knowledge of God, mathematics, morality, and oneself is superior to that of external objects. This peculiar, seemingly subjective overtone in Locke's epistemology should not be overstated, however. Locke does not support enthusiasm or excessive subjectivism, and even his apparent metaphysical reflections are based, at least so Locke thinks, on human historical experience.

When it comes to political philosophy, Locke developed his system in response to the typical medieval idea represented in his time by Sir Robert Filmer (and many others in all royal houses across Europe) that human individuals are born as serfs, naturally unfree, subject to the divine rule of God as mediated by the divinely appointed earthly ruler (a king, prince, magistrate, etc.). Much like God wields absolute power in the heavens above, the earthly sovereigns, vested with power from above, naturally wield the same power of their temporal subjects. (Cuttica, 2016; Daly, 2017) To further solidify this understanding of the governing political order, the intellectual apostles of this theory set out to invent suitable exegetical twists of the corresponding biblical texts. Filmer was a good example of such exegetical violence.

Locke refutes such biblical exegesis as grossly inadequate and ideologically laden, fitted to empower tyrants in their arbitrary lust for power. When it comes to Filmer's theory of the intrinsic serfdoms of all human subjects born into the realm governed by a dutifully appointed sovereign, Locke resorts to a permeating analysis of human history, demonstrating that any such rule exhibit signs of brute force and random violence, the result of which was injustice, poverty, and social instability. Next, Locke comes up with a new kind of anthropology, the roots of which are situated in theological, biblical anthropology. His competing exegesis of the core biblical texts (namely from Genesis 1-3 and some Psalms) leads him to formulate his 'natural rights' theory. To some extent, we may argue that this theory, too, comes from Locke's investigation of 'the state of nature' - which is typologically an empirical-reflective endeavor. Locke asserts that the 'state of nature' "has a law of nature to govern it, which obliges every one: and reason, which is that law, teaches all mankind, who will but consult it, that being all equal and independent, no one ought to harm another in his life, health, liberty, or possessions: for men being all the workmanship of one omnipotent and infinitely wise Maker; all the servants of one sovereign Master, sent into the world by his order, and about his business; they are his property, whose workmanship they are, made to last during his, not another's pleasure." (Locke, 2003: 6) Locke believes in both - the power and responsibility of human reason to discern the law of nature, which posits that all mankind are born into this world as equal and independent, with vested dignity as the bearers of the image of their Maker. Therefore, "being furnished with like faculties, sharing all in one community of nature, there cannot be supposed any such subordination among us that may authorize us to destroy another, as if we were made for one another's uses, as the inferior ranks of creatures are for ours. Every one, as he is bound to preserve himself, and not to quit his station wilfully, so by the like reason, when his own preservation comes not in competition, ought he, as much as he can, to preserve the rest of mankind, and may not, unless it be to do justice to an offender, take away or impair the life, or what tends to the preservation of life, the liberty, health, limb, or goods of another." (Locke, 2003: 6)

XLinguae, Volume 15 Issue 1, January 2022, ISSN 1337-8384, eISSN 2453-711X 
We can observe that Locke's concept of law of nature is foundational for his further deliberation concerning natural rights that are intrinsic to all humans (they are, so to speak, innate properties of all human individuals). This concept of law of nature reveals Locke's presupposition that nature (representing all reality) has order bestowed upon it by the intentional act of its Maker. Humans are responsible for using their faculty of reason to discern and apply the law of nature in their own lives and societies. The most basic law governing all humans and, in fact, all living creatures is the law of survival (connected to the first human natural right, the right to life). This is a comprehensive task but also an inner drive (or instinct) that explains and, indeed, demands the recognition of three other fundamental rights. The right to liberty, preserving one's health, and the right to own possessions are all constitutive to preserving and enacting the first fundamental right to life.

The need for a government arises from the fact that human individuals driven by their will to survive (which is both their fundamental right and task/responsibility) will not likely behave in an orderly, rational, and just manner when left on themselves. (Locke 2003: 50) Thus, to protect their wellbeing and a fair administration of their rights, they curb the free exercise of their rights and delegate some power and responsibility onto a government. An elected institution/government is, according to Locke, in a better position to administer justice than the afflicted individual or his immediate relatives, who may act in anger and who tend to retaliate against injustice with even greater injustice.

For a legitimate government to arise, a new social contract must be crafted, agreed upon, and implemented in human society. Justice, prosperity, and stability can only be achieved in an "ordered," i.e., law-bound human community. This necessarily infringes on the freedoms of the given community members who - to the minimum necessary extent - give up their arbitrary exercise of freedoms that are derived from their intrinsic, innate rights. They still keep these rights; only the way they exercise them, or the extent to which they express them in their choices and interactions with each other and with the state institutions, is limited by the social contract. The point is that the social contract is drafted by the people for the protection of their rights and freedoms. The fact that these freedoms are limited is only a necessary precondition, a means to an end, never the end itself. The key for the social contract to work is that a critical majority of the citizens come to a solid understanding of the state of nature and the corresponding law of nature by using their faculty of reason. Also, suppose people are to be governed by a prince or a ruler. In that case, they must know this person and his credentials, and it also must be made public whether or not this person accepts the mutually binding arrangements of the social contracts. As Locke puts it, "there must be ways of designing, and knowing the person to whom this regal power of right belongs; and a man can never be obliged in conscience to submit to any power, unless he can be satisfied who is the person who has a right to exercise that power over him." (Locke, 2003: 81) Without the informed consent of the governed, there can be no legitimate government. This process can be implemented in diverse political settings - whether it is a monarchy, some kind of aristocratic establishment, or various forms of democracy.

\section{Contemporary discourse related to Locke's ideas in the West (with a focus on property rights and the value of labor)}

There is a lively debate in the West concerning how to interpret and assess Locke's legacy. Among the most hotly debated issues are the content of Locke's notions of 'natural rights' and the viability of his 'social contract' theory in different geopolitical and cultural contexts. Opposing camps are not aligned merely along the typical East/West divide or the rich North, poorer South divide. More profound ideological divisions become apparent when evaluating and interpreting Locke's heritage. 
We can observe this poignantly among scholars who debate the similarities and dissimilarities between Karl Marx and John Locke. There are those like Hugh Breakey, who, in his chapter on "Arbitrary Power, Arbitrary Interference and the Abuse of Power: Corruption, Natural Rights and Human Rights" (Breakey, 2017), explores the relationship between corruption and human rights in a diverse array of political settings. Breakey belongs to the group of scholars who tend to emphasize the dissimilarities between Locke and Marx. Also, Breakey argues in his chapter that "the deep thematic links between systemic corruption and violations of human rights are stronger than have hitherto been recognized," and that "corruption should be recognized as a 'standard threat' to human flourishing and protected freedoms, vindicating the human right to freedom from systemic corruption." (Breakey, 2017: 125) Joshua Glawson in his article "Labor and Property: Locke vs. Marx," (Glawson, 2018) focuses on the differences in essential concepts related to understanding the nature of property and labor between Locke and Marx. Glawson admits Locke's seemingly ambiguous stance on property. There is the looming danger of "Covetousness, and the desire of having in our possession, and under our dominion, more than we have need of," which Locke considers "the root of all evil." (Locke, 1996: 3) Like Marx after him, Locke opines that such covetousness "should be early and carefully weeded out, and the contrary quality of a readiness to impart to others, implanted." (Locke, 1996: 3) This is not to be interpreted in strictly Marxist terms, however. Locke was quick to balance his emphasis on fighting against covetousness for possessions with an equally strong emphasis on the right to personal property as a means of sustenance and expression of justice, providing the possession was obtained in a legal way. (Haddad, 2003) Another proponent of stressing the contrast between Locke and Marx is Adam Mossoff (2012) who in his recent article "Saving Locke from Marx: The Labor Theory of Value in Intellectual Property Theory" argues that we should not succumb to the error of redefining "Locke's concepts of labor and value into physical and economic terms," which is, according to Mossoff, "more akin to Karl Marx's labor theory of economic value." Mossoff employs the so-called "principle of interpretative charity" to reevaluate Locke's labor theory of value against the background of his natural law ethical theory. Without the proper context, i.e., Locke's natural law ethical theory (See especially: Locke, 1975), can easily be misinterpreted. Mossoff identifies Locke's "An Essay Concerning Human Understanding" as the work with the most complex and clear description of Locke's natural law ethical theory. Among other things, Mossoff reminds his opponents that Locke's concept of labor is much more robust than they typically admit, as it includes physical as well as intellectual means of production. Furthermore, when it comes to Locke's concept of "value," this, too, should not be reduced to economic status or physical wealth and wellbeing. Value is linked to the good life of a rational human being; it encompasses comprehensive human flourishing, not just money and goods. (Reno, 2009) When seen from this perspective, it is clear that much of the criticism leveled against Locke by the likes of Hettinger (1989), Nozick (1974), or Cohen (1995; Cf. Williams, 1992) is unfounded.

The other side of the philosophical barricade are those who either argue for a measured affinity between Marx and Locke (on selected issues) or criticize Locke's liberalism and alleged 'individualism' (Macpherson, 1964) favoring instead the classical Marxist doctrines pertaining to labor and property. This group is represented by scholars, such as Murat Birdal (2007), Laura Dehaibi (2015), Charles Rupert (2017), and Jukka Gronow (2015). These scholars portray Locke as one of the founders of Western liberal capitalism, dramatically at odds with Marx, especially in his views on the nature of labor and the rights to individual property. (Do \& Valco, 2021a)

XLinguae, Volume 15 Issue 1, January 2022, ISSN 1337-8384, eISSN 2453-711X 
A good example of such a critical attitude towards Locke is exemplified by Dehaibi's critical stance to the typical Western liberal conception of property rights. "Property rights in Western societies are traditionally framed as negative and individual rights their central feature is the right to exclude. This normative framework is influenced by liberal theory, which privileges individual liberties and free-market ideology. Rather than serving everyone equally, property rights reinforce social inequalities by providing greater protection to entitlements for a small and privileged group of individuals." (Dehaibi, 2015: 1) This concern is echoed by other scholars mentioned above. To illustrate this, we will examine Murat Birdal's and Crawford Macpherson's critical analyses of Locke.

The primary value of Locke's legacy, according to Macpherson (1964), rests in his "assertion of the free rational individual as the criterion of the good society." (Macpherson, 1964: 262). However, historical experience teaches us that only some fall into the category of the 'rational and industrious,' which results in the land and most of the available resources being appropriated by the 'rational and industrious' few at the expense of the rest. The majority of the citizenry, then, are left "with the only option of selling their labor to stay alive." Furthermore, "individuals no longer have a natural right to landed property and the propertyless that are dependent on the others are also subject to their jurisdiction." (Birdal, 2007: 59) Birdal correctly points out the stark contrast on this issue between Marx and Locke. Instead of the notion of 'natural rights' or a philosophical conception of 'justice,' Marx bases his theories of rights and labor on analyzing the mode of production. The private property does not need to determine an individual's rights, providing "every mode of production creates its own cultural values and moral standards." (Birdal, 2007: 59) Locke seems to miss this point entirely. Hence his insistence on the right to private property as constitutive to one's other rights and freedoms - or at least such is Birdal's interpretation of Locke's notion of the value of labor and property rights. As a result, "private property gains a social character that reproduces the dominance of one class over the other." (Birdal, 2007: 60) At the core of Birdal's and other Marxists' critique of Locke's economic and political liberalism is the notion human persons' freedom must necessarily be linked to their right to own property. The right to property thus becomes essential, constitutive to not only human freedom but also his value and political rights and status. In contrast to this, Marx and Marxist (or left-leaning) philosophers in the West link this insistence on the right to private property with excessive individualism, which ultimately leads to the dehumanization of the lower classes, as they become alienated from the fruits of their labor and stripped of their social and political rights. Human beings are in danger of becoming a commodity on the market, and their insistence on the right to own property becomes dehumanizing, enslaving force with grave internal (intrapsychic) and external consequences.

Macpherson goes on to warn against the ambiguous character of the Western notion of individualism as foundational for classical liberal theories in the West. He points out that thusly conceived individualism has 'possessive quality' which is detrimental for the society as well as interpersonal relationships. Macpherson then offers seven propositions that summarize the character and content of possessive individualism:

"(1) What makes a man human is freedom from dependence on the wills of others.

(2) Freedom from dependence on others means freedom from any relations with others except those relations which the individual enters voluntarily with a view to his own interest.

(3) The individual is essentially the proprietor of his own person and capacities, for which he owes nothing to society.

(4) Although the individual cannot alienate the whole of his property in

his own person, he may alienate his capacity to labour.

(5) Human society consists of a series of market relations. 
(6) Since freedom from the wills of others is what makes a man human, each individual's freedom can rightfully be limited only by such obligations and rules as

are necessary to secure the same freedom for others.

(7) Political society is a human contrivance for the protection of the individual's property in his person and goods, and (therefore) for the maintenance of orderly relations of exchange between individuals regarded as proprietors of themselves." (Macpherson, 1964: 263-264)

This reductionist understanding of the essence of humanity prompts human individuals to seek 'freedom from dependence' on others. Human mutuality and interdependence of diverse stakeholders in the human community are thus naturally diminished. Under these conditions, human societies feel less like communities and more like institutionalized systems of economic and political relations in which the more successful one is, the more independent/isolated he is from the needs and concerns of others. The political system then tends to be abused by the wealthy and successful with a strong incentive to maintain the status quo based on the principle of private property rights.

Macpherson further rightly observes the ambiguous nature of Locke's theory of "differential membership" in civil society - a concept that enables Locke to approve the existing class divisions in his society. More concretely, Locke notices the differential use of one's rationality and free will in pursuing one's natural rights, among them, namely the right to earn and own property. Therefore, even if everyone is born equal (with equal rights), human societies are divided into classes based on the meritocratic achievements of their individual members. Hence the concept of 'differential membership' of citizens in society. Such meritocratic perspective, undoubtedly deemed 'rational' by Locke, veiled "the contradiction in his individualism, in which full individuality for some was produced by consuming the individuality of others." As Macpherson incisively asserts, "Locke could not have been conscious that the individuality he championed was at the same time a denial of individuality. Such consciousness was not to be found in men who were just beginning to grasp the great possibilities of individual freedom that lay in the advancement of capitalist society. The contradiction was there, but it was impossible for them to recognize it, let alone to resolve it." (Macpherson, 1964: 261-262)

\section{Conclusion}

Locke's legacy for political philosophy and human rights discourse (both then and now) remains highly significant. Though the interpretations and evaluations of his ideas vary, his notions of 'law of nature,' 'state of nature,' 'natural rights,' 'social contract,' as well as his empiricist epistemology and inductive reasoning based on historical experience contributed to the breeding ground of modern, European Enlightenment. Locke's notions and ideational starting points cannot be isolated from his overall 'worldview,' i.e., his theistic metanarrative and metaphysical presuppositions. We should, therefore, critically reflect on the question of whether Locke's original metaphysical presuppositions were necessary for his thinking to emerge and attain coherence or whether it was merely a historical contingency that had no definite bearing on the result. We did not see this discussed as much as we would have expected (or liked to) in contemporary literature. Can we meaningfully articulate the idea that humans possess 'human nature' if we give up a certain 'vision of reality' as being ordered, created with a purpose? (Turcan, 2021: 40) These are difficult problems. "Being essentially Deist, Locke held certain presuppositions about the reality of the world, which he considered the result of an intentional, deliberate act of creation. Hence his insistence on the existence of a governing, all-pervasive natural law (or the law of nature)." (Do \& Valco, 2021a: 14) Should we take Locke's

XLinguae, Volume 15 Issue 1, January 2022, ISSN 1337-8384, eISSN 2453-711X 
essentialist language at face value, or can we interpret it as linguistic metaphors unrelated to the original metaphysical presuppositions? This is no mere play on words. If the Universal Declaration of Human Rights from 1948 is to have general, universal validity, we must explain on what foundations can the text base its claims to be universally valid. Foundational questions of anthropology are not easily avoidable within our wider effort to understand the nature and universal applicability of human rights. (Pala, 2017; Kardis, 2008; Tkacova \& Slivka, 2021)

Most of the current debate on the value of Locke's legacy and how it should be interpreted today revolves around the question of how the 'law of nature' "morphed into our modern conception of 'human rights' and how theories of contract [...] limited the power of the monarchs, which eventually led to democracy and the rule of law as based on human dignity and inalienable freedoms." (Do \& Valco, 2021a: 14) Another pertinent question relates to the problem of 'individualism' as it has been conceived in the West ever since the dawn of the Enlightenment. This individualism is not just a superficial cultural feature or a challenge for interpersonal relationships. It is an underlying force behind economic modes of production and other types of economic relations, and it has significance for property rights as well. This theme comes to the fore in the neo-Marxist interpreters of the history of Western thought, most notably of Locke's notion of the right to property, as we have seen in the section above. While some like to emphasize a more radical, critical detachment of Marx from economic and political liberals, such as Locke, others perceive Marx as a creative genius who is able to draw on the rich tradition of Western thought and integrate useful emphases from thinkers who are considered members of the opposing camp. (Engle, 2011).

\section{Acknowledgements}

This research is funded by Vietnam National Foundation for Science and Technology Development (NAFOSTED) under grant number 603.01-2020.300

\section{Bibliographic references}

Birdal, M. (2007). "Locke's Theory of Property and Its Marxist Critique: Locke and Marx on Property Rights and Individual Liberties.” İktisat Fakültesi Mecmuas1, 57(1), 39-61.

Breakey, H. (2017). Arbitrary Power, Arbitrary Interference and the Abuse of Power: Corruption, Natural Rights and Human Rights. In Savur, S. and S. Sandhu (eds.), Responsible Leadership and Ethical Decision-Making. Bingley, UK: Emerald Publishing Limited, 125-145.

Cohen, G. A. (1995). Self-Ownership, Freedom and Equality. Cambridge: Cambridge University Press.

Cuttica, C. (2016). Sir Robert Filmer (1588-1653) and the patriotic monarch: Patriarchalism in seventeenth-century political thought. Manchester: Manchester University Press.

Daly, J. (2017). Sir Robert Filmer and English Political Thought. Toronto: University of Toronto Press.

Dehaibi, L. (2015). "The Case for an Inclusive Human Right to Property: Social Importance and Individual Self-Realization.” Western Journal of Legal Studies, 6(1) [online]. Available at: http://ir.lib.uwo.ca/uwojls/vol6/iss1/5.

Do, T.K.H. and M. Valco. (2021a). "Thinking with John Locke about the nature of human rights: Vietnamese and global perspectives.” XLinguae, 14(3), 3-18.

Do, T.K.H. and M. Valco. (2021b). "Exploring the Presuppositions and Context of John Locke's Thoughts on Human Rights.” Theologos, 23(2), 18-29.

Engle, E.A. (2011). "Karl Marx's Intellectual Roots in John Locke” (September 15, 2008). Postmodern Openings, 7(1), 29-37 [online]. Available at: https://ssrn.com/abstract=1268545. 
Filmer, R. (1865). Patriarcha, or: The natural power of Kings. London: R. Chiswel, W. Hensman, M. Gilliflower, and G. Wells Press, 1865 [republished in London, 1980]. Glawson, J.D. (2018). Labor and Property: Locke vs Marx. Medium.com [online]. Available at: https://medium.com/@JoshuaGlawson/labor-and-property-locke-vsmarx-b1b79f34193b

Gronow, J. (2015). John Locke, Adam Smith and Karl Marx's Critique of Private Property. In On the Formation of Marxism: Karl Kautsky's Theory of Capitalism, the Marxism of the Second International and Karl Marx's Critique of Political Economy. Leiden - Boston: Brill, 225-251.

Haddad, B. (2003). "Property rights, ecosystem management, and John Locke's labor theory of ownership." Ecological Economics, 46(1), 19-31.

Hettinger, E. C. (1989). "Justifying Intellectual Property," Philosophy \& Public Affairs 18(1), 36-40.

Hobbes, T. and M. Missner. (2016). Thomas Hobbes: Leviathan (Longman Library of Primary Sources in Philosophy). London: Routledge.

Kardis, K. (2008). Otazka zakladných hodnot a principov v kontexte multikulturneho dialogu. In Dancak, P. and D. Hruska (eds.), DISPUTATIONES QUODLIBETALES. Presov: Presovska univerzita v Presove, 69-88.

Locke, J. (1975). An Essay Concerning Human Understanding. In P. H. Nidditch (ed.), The Clarendon Edition of the Works of John Locke. Oxford: Clarendon Press. doi:10.1093/actrade/9780198243861.book.1/actrade-9780198243861-book-1.

Locke, J. (1996). Some Thoughts Concerning Education; and The Conduct of the Understanding. R.W. Grant and N. Tarcov (eds.). Indianapolis: Hackett Publishing Co. Locke, J. (2003). Two Treatises of Government and A Letter Concerning Toleration. I. Shapiro (ed.). New Haven - London: Yale University Press.

Macpherson, C.B. (1964). The Political Theory of Possessive Individualism: Hobbes to Locke. Oxford - New York: Oxford University Press.

Mossoff, A. (2012). "Saving Locke from Marx: The labor theory of value in intellectual property theory." Social Philosophy and Policy, 29(2), 283-317.

Nickel, N. (2019). Human Rights. In Edward N. Zalta (ed.), The Stanford Encyclopedia of Philosophy (Summer 2019 Edition). [online]. Available at: https://plato.stanford.edu/archives/sum2019/entries/rights-human/.

Nozick, R. (1974). Anarchy, State and Utopia. New York: Basic Books, Inc.

Pala, G. (2017). "The Theological View of Social Work: A Contribution to the Social Science vs. Religion Debate." European Journal of Science and Theology, 13(3), 3545 .

Reno, J. (2009). "Private Property and the Law of Nature in Locke's Two Treatises The Best Advantage of Life and Convenience." American Journal of Economics and Sociology, 68(3), 639-663.

Rickless, S. (2020). Locke On Freedom. In Edward N. Zalta (ed.), The Stanford Encyclopedia of Philosophy (Spring 2020 Edition). [online]. Available at: https://plato.stanford.edu/archives/spr2020/entries/locke-freedom/

Rupert, C.M. (2017). "Locke, Marx, and Two Theories of Labor. A philosophical Essay on how to fix our political economy." [online]. In Next system project national essay competition, 2017 [online]. Available at: https://thenextsystem.org/sites/default/files/2017-07/Rupert_GraduateFirst.pdf

Tkacova, H., \& D. Slivka. (2021). "The Christian Ideal of Sustainable Development and Its Perception among Young Adults: A Case Study from Slovakia.” Religions, 12(10), 882. DOI: https://doi.org/10.3390/rel12100882

Tuckness, A. (2018). Locke's Political Philosophy. In Edward N. Zalta (ed.), The Stanford Encyclopedia of Philosophy (Summer 2018 Edition). [online]. Available at: https://plato.stanford.edu/archives/sum2018/entries/locke-political/ 
Turcan, M. (2021). Ludske prava v kontexte krestanskej teologie dnes. Praha: AdventOrion.

Williams, A. (1992). “Cohen on Locke, land and labour.” Political Studies, 40(1), 5166.

Words: 6151

Characters: 40621 (22,57 standard pages)

Dr. Hoa Thi Kim Do, PhD.

Institute of Philosophy

Vietnam Academy of Social Sciences

59 Langha, Badinh, Hanoi

Vietnam

hoatuanphuc@gmail.com

prof. PhDr. Michal Valco, PhD.

Evangelical Lutheran Theological Faculty

Comenius University in Bratislava

Bartokova 8

81102 Bratislava

Slovak Republic

michal.valco@uniba.sk

Kazan Federal University

Institute of Psychology and Education

Kremlyovskaya Str. 18

RU - 420008 Kazan

Russian Federation 